\title{
SERVICE-LEARNING AS PART OF THE L2 SPANISH CLASSROOM IN CANADA
}

\author{
Ewelina Barski and Camelia Nuñez \\ The College at Brockport, SUNY, USA \& University of Waterloo, Canada
}

\begin{abstract}
Service-learning in foreign language classrooms is an effective resource for developing language motivation. Unfortunately, Canadian language programs have been off to a slow start in adopting integrative teaching such as service-learning in their foreign language curricula (Hale, 1999). This work reports on a Community Service Learning (CSL) initiative introduced at a Canadian university in the Hispanic Studies program. A total of fifty second and third year Spanish language students volunteered with various community partners on a weekly basis for a total of sixteen weeks. End-of-term questionnaire indicates that overall students had a favorable experience at their placement and CSL had a positive influence in continuing their studies in Spanish.
\end{abstract}

Keywords: Canada, Community Involvement, Service-Learning, Experiential Learning, Language Acquisition, Spanish.

\section{APRENDIZAJE A TRAVÉS DE SERVICIO COMO PARTE DE LA CLASE DE ESPAÑOL L2 EN CANADÁ}

\section{RESUMEN}

El aprendizaje a través de servicio en las aulas de idiomas extranjeros constituye un recurso eficaz a la hora de desarrollar la motivación de los estudiantes por el idioma. Lamentablemente, los programas de idiomas canadienses han tenido un lento inicio en la adopción de un tipo de enseñanza integradora como lo es el aprendizaje a través de servicio en sus planes de estudio de idiomas extranjeros (Hale 1999). Este ensayo examina una iniciativa de aprendizaje a través de servicio comunitario (CSL) introducida en el Programa de Estudios Hispánicos de una universidad canadiense. Un total de cincuenta estudiantes de segundo y tercer año de español asistieron semanalmente como voluntarios a varias asociaciones comunitarias durante un total de dieciséis semanas. El cuestionario administrado al final indica que, por lo general, los estudiantes consideraron favorablemente la experiencia y muestra también cómo el CSL influyó de manera positiva en la decisión de continuar sus estudios de español.

Palabras Clave: Canadá, participación comunitaria, aprendizaje de servicio, aprendizaje experimental, adquisición de lengua, español.

DOI: https://doi.org/10.25145/j.recaesin.2020.81.20

Revista Canaria de Estudios Ingleses, 81; November 2020, pp. 30-319; ISSN: e-2530-8335 


\section{INTRODUCTION}

The aim of this paper is two-fold: first, we will present a new model of incorporating Community Service Learning (CSL) into the Spanish language curriculum at a Canadian university and secondly, we will report our findings on a post-CSL questionnaire completed by the Spanish students who opted for servicelearning as part of their language learning experience. Our results show that the CSL experience has a positive impact on students' intent to further pursue Spanish courses as well as on their overall learning experience.

It has been well established that the language learning process for a child is distinct from that of an adult. While a child learning a first language is guaranteed to succeed (in natural conditions), an adult who has a fully developed first language and wants or needs to learn a second language is not guaranteed that same success. Montrul (2008) explains that the key differences in the two language acquisition processes are quality and quantity of input, personality and affective factors, and the outcome of the target system. Most importantly for the purpose of this paper, personality and affective factors only become a relevant issue with adults. Gass and Selinker (2008) demonstrate that there are many different "non-language factors" involved in the acquisition of a second language such as "age, aptitude, motivation, attitude, and socio-psychological influences" (Gass \& Selinker 395). With this in mind, this work will demonstrate how a student's own motivation can be positively influenced by taking part in a CSL program.

\section{WHAT IS SERVICE-LEARNING}

One of the first definitions provided for service-learning was in 1979 by Robert Sigmon who explained it as a form of experiential education that is based on "reciprocal learning" (Sigmon, 1979). The idea behind this was that since learning comes from the service organization, both those who provide the service and those who receive it, must learn something from the experience. According to Sigmon, service-learning is successful only when both parties involved -the students and the service provider-benefit from the relationship. Today, although Sigmon's definition still holds true, Bringle and Hatcher (1996) take it one step forward, as outlined below:

Unlike extracurricular voluntary service, service-learning is a course-based service experience that produces the best outcomes when meaningful service activities are related to course material through reflection activities such as directed writings, small group discussions, and class presentations. Unlike practica and internships, the experiential activity in a service-learning course is not necessarily skill-based within the context of professional education (Bringle \& Hatcher 222).

There are therefore two streams to service-learning: Curricular and co-curricular. In co-curricular programs, the work that the students do is not for credit and they include placements such as "alternative spring break" where students 


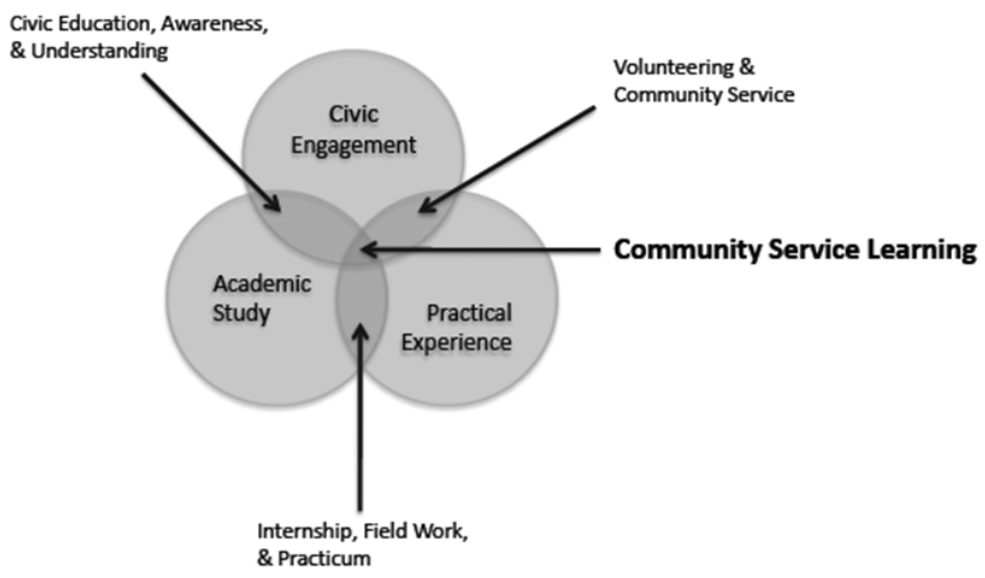

Figure 1. Visual definition of Community Service Learning.

Was adapted from the Student Success Centre and

Community Service Learning at Western University.

spend their spring break working for an organization, on their own time and for their own personal reasons. The stream that we are mainly concerned with here is the curricular one where students are graded for their work in the community as well as in the classroom. It gives students a chance to apply skills and knowledge acquired in the classroom to real-life situations, and at the same time it requires them to produce at least one reflection. As mentioned by Bringle and Hatcher, students are graded on reflections that are prepared as part of their in-class work and these may take several modes such as writing, telling, reading, and doing. It is important to note that reflections are not a didactic retelling of the events at a service site, nor are they an emotional outlet for feeling good about doing service, or feeling guilty about not doing more. Students need to be able to link their placement experience with the classroom but also with their own personal growth.

Astin, Vogelgesang, Ikeda and Yee (2000) have shown that Curricular CSL has positive effects on students in terms of their academic learning (grades, critical thinking, writing skills), personal growth (self-efficacy, moral development), social development (appreciation of diversity, social responsibility), career development, and in their overall engagement with the institution. From the point of view of the faculty who teach a CSL course, Astin and company report that faculty are satisfied with the quality of student learning and there is an increasing desire to integrate CSL in courses, however there is a lack of resources and reward for the professors which act as barriers. From the community's point of view, they have found that students provide knowledge, skill, or expertise that may fill an existing gap and they offer fresh perspectives to problems that may not have been solved as easily without this type of collaboration. 
Figure 1 visually explains that service-learning is composed of academic study, civic engagement, and practical experience. As can be seen, where the academic study and civic engagement components overlap, it is expected that the student develop a form of civic education, awareness, and understanding of their role in the community. Civic engagement and practical experience make volunteering and community service possible, while practical experience and academic study provide the opportunity for internships, field work and practicum placements.

\section{CSL AND LANGUAGE COURSES}

When it comes to the second language classroom, the question that arises is: how can language educators combine academic goals and civic engagement, while maintaining motivation? In Canadian universities in particular, the initiatives of making CSL part of the foreign language class have been scarce. In most of the cases, the reason has been attributed to the lack of opportunity of effectively merging the academic requirements with the practical side. However, previous experiences have clearly shown (see for example Barreneche, 2011) that local organizations that deal with immigrants and newcomers are great opportunities for foreign language students to apply their classroom-acquired skills into the "real world". Countries such as the US and Canada, with ever-growing immigrant populations and an extensive number of organizations to serve these communities, can and should certainly explore these opportunities. Nonetheless, even south of the Canadian border, in the US, it seems that language programs have been off to a fairly slow start in adopting integrative teaching such as community service in their foreign language curricula (Hale, 1999).

The 1999 publication by the American Association for Higher Education (AAHE), Construyendo Puentes: Concepts and Models for Service-Learning in Spanish, as well as the AATSP Professional Development Series Handbook Juntos: Community Partnerships in Spanish and Portuguese (2004) are the two of the earliest attempts at documenting the service-learning experience as part of the Spanish classroom. Further publications in the field (extending to other languages) are Wurr and Hellebrandt's edited volume Learning the Language of Global Citizenship: Servicelearning in Applied Linguistics (2007) as well as a considerable number of papers that appeared in academic journals such as Hispania, Foreign Language Annals, as well as the Michigan Journal of Community Service-Learning. Furthermore, two Spanish language instructional textbooks -En comunidad (2008) and Comunidades (2009) -with a focus on community engagement have also been made available to language educators.

Although, for many disciplines, CSL has been gaining momentum in Canadian universities as well, there are very few cases where this kind of learning has been adopted in the language classroom. For Spanish, there is one experimental CSL project reported on and it comes from the University of Alberta. Zapata and Tokarz (2008) and Zapata (2011) studied the impact of CSL on students' cultural understanding. In the first paper, the authors focused only on the effects of the 
CSL experience on high-intermediate language learners, while the second one was expanded to include learners at the beginner level. Both studies point to the fact that service-learning is an essential instrument in the process of building intercultural communicative competence. As reported by the authors, these findings were consistent with those of others studying this phenomenon in the US, such as Beebe and De Costa (1993) and Varona (1999). In her 2011 study, Zapata brings up an important factor, which is that of the proficiency level in the target language. The author indicates that because of their limited knowledge of Spanish, students at the low-intermediate level were also limited in the duties they could perform during their CSL project. Zapata suggests that the participants' low proficiency level may have hindered their "overall perception of the project and their attitudes, all of which may have been the result of poorly articulated objectives and CSL duties" (Zapata 99).

As previously mentioned, motivation in adult language learners plays a vital role in maintaining interest and in continuing their study in the language. Lightbown and Spada (2008) mention two common types of motivation, which are linked to language learning: Integrative motivation and instrumental motivation. First coined by Gardner and Lambert (1972), integrative motivation refers to "language learning for personal growth and cultural enrichment, and instrumental motivation ... [refers to] language learning for more immediate or practical goals" (Lightbown $\&$ Spada 56). Both types of motivation play a crucial role because that is what drives the students to sign up for Spanish and in this case, choose to incorporate the CSL component into their learning experience.

Dörnyei (2000) proposes a motivation model, which allows for changes to occur over time. This model is composed of three temporal stages. The first stage is called the preactional stage, which is where wishes, hopes, desires, and opportunities turn into actual goals, and where motivation is generated. With respect to our students, this stage creates intention and commitment to register for Spanish, for example. Some of the motivational influences may be attitudes toward the L2 and its speakers, expectancy of success, and environmental support. The next stage is called the actional stage and this is where our students actually embark on the task (of signing up for a language class) and "the individual has committed him/ herself to action and now the emphasis shifts from deliberation and decisionmaking to the implementation of action" (Dörnyei 2000, 527). In this stage a few of the motivational influences include quality of the learning experience, teachers' and parents' influence, and classroom reward and goal structure, whether it is competitive or cooperative (Dörnyei, 2005). The third stage of the motivation model is the postactional stage. In this final stage the completion of the action takes place. Dörnyei (2000) explains that "the main processes during this phase entail evaluating the accomplished action outcome and contemplating possible inferences to be drawn for future actions" (Dörnyei 2000, 528). Once the action is completed, the student reflects on what was expected at the initial onset of the goal and whether or not it was accomplished as first predicted. In the case of language students, the postactional stage is where they decide whether or not to continue with Spanish in the next semester or school year. Our study demonstrates that participation in a CSL program can positively influence the actional stage, which causes a positive 
postactional stage, which in turn motivates our students to continue with learning Spanish as a second language.

\section{CURRENT STUDY}

This section describes in detail the implementation process of the CSL component as part of the course curriculum for all intermediate and advanced Spanish language courses at Western University in London, Ontario, Canada. The idea of giving students the CSL option was motivated in great part by the CSL success stories mainly undertaken in the USA and secondly, the relatively large Hispanic population in the city of London, Ontario (as compared to others in Canada). Furthermore, the many organizations working with this community have made it possible for us to offer students a variety of opportunities to get involved.

As such, during the summer months (prior to the beginning of the academic year), with the support of the office for Service-learning at Western University, we began our work in establishing relationships with different associations in the city as well as determining the logistics of making CSL part of the Spanish classes. It was our goal that by participating in CSL, students would be able to:

1. Get a better understanding of the socio-cultural setting of the Hispanic community in London.

2. Have the opportunity to put into practice classroom-acquired knowledge in real life situations.

3. Establish friendly relations with members of the London Hispanic community. 4. Identify similarities and differences between Canadian and Hispanic cultures.

Thus in September 2010, Hispanic Studies became the first language program at Western University and the second in Canada to incorporate CSL as part of the curriculum for the intermediate and advanced Spanish courses. This initiative continued in the following academic year 2011-2012 and has now become a regular part of the academic curriculum for Spanish language courses at these levels. In this paper however, we will focus on thoroughly discussing our first year experience as well as the results we obtained from a post-CSL questionnaire completed by the participating students.

\subsection{The Course Curriculum}

The CSL option was made available to all intermediate and advanced language learners: six intermediate and three advanced sections, a total of approximately 200 students. Each course is eight months long (a total of two semesters) and both are fully taught in Spanish. Intermediate Spanish provides students who already possess knowledge of basic grammatical structures with more advanced training in the Spanish language. The primary emphasis is on effective oral 


\begin{tabular}{|c|c|}
\hline & \\
\hline & bs (participation, preparation, etc.)...10\% \\
\hline Assignments (oral and written) $\ldots \ldots \ldots \ldots . .5 \%$ & Assignments (oral and written)............5\% \\
\hline Quizzes (around 5), ...................... & Quizzes (around 5).... \\
\hline 3 (out of 4 ) tests (gramm & 3 (out of 4 ) tests (gram \\
\hline $30 \%$ & comprehension and compositions) \\
\hline 4 reflective Blog Posts.... & 4 compositions (home).. \\
\hline 1 Oral presentc & $\ldots 8 \%$ \\
\hline \multicolumn{2}{|l|}{ Evaluation by community partners.... $10 \%$} \\
\hline Final exam....... & Final exam.... \\
\hline otal CSL $30 \%$, Regular $70 \%, \quad 100 \%$ & Total \\
\hline
\end{tabular}

Figure 2. SP 2200 (Intermediate) Course Syllabus.

and written expression, so as to permit students who have completed this course to communicate their ideas and opinions with clarity in a variety of academic and social settings. Advanced Spanish is offered to third year Spanish students who already have knowledge in Spanish but wish to improve in both oral and written forms. The goal is that all students be able to express themselves in spontaneous contexts and be able to understand extensive discourses (oral) such as TV shows and movies. Because of the language limitations for all first year students (also pointed out by Zapata, 2011), CSL was not offered to this group of students. In total, there were forty-seven CSL placement slots available for students and they were assigned on a first come first serve basis to those who expressed interest. Furthermore, students were given the option of listing three preferred organizations, which allowed us to place them accordingly. To our content, the CSL initiative was received with much enthusiasm: a total of eighty students expressed interest in this program.

Below is a detailed description of how CSL was included in the Spanish course curriculum. Overall, the CSL component was evaluated at 30\% of the final grade and it was to replace other regular class activities that non-CSL students had to complete. As opposed to the CSL program carried out at the University of Alberta (see Zapata and Tokarz, 2008, and Zapata, 2011), the class instructor was not responsible for the students' performance in the CSL option. Rather, a CSL coordinator was assigned and was made responsible for all CSL activities as well as the evaluation of all students that chose this option.

For a clearer explanation, Figure 2 and Figure 3 show the grade breakdown as it was outlined in the course Syllabus for intermediate (SP 2200) and advanced (SP 3300) students.

As can be seen in both syllabi, students at both levels had two options. For those who chose to participate in CSL, some of the regular program requirements were replaced with the following: four reflective blog posts $(12 \%)$, one oral presentation on 


\section{OPCIÓN 1 - COMMUNITY SERVICE LEARNING \\ Blog Post $(4 \times 3)$.................... 12\% \\ Presentación oral CSL .............. 8\% \\ Evaluación Community Partners .. 10\%}

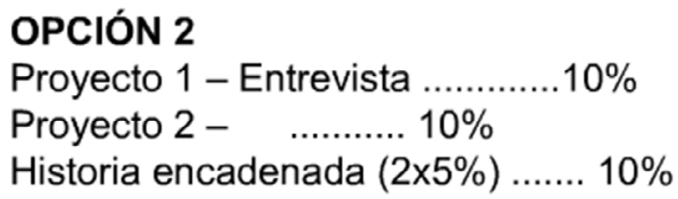

Figure 3. SP 3300 (Advanced) Course Syllabus.

the CSL experience (8\%), and a final evaluation by the community partner $(10 \%)$. The assigned CSL coordinator in the department was responsible of grading each of the reflective blogs, the final presentation, as well as maintaining regular contact with the community partner, who provided the coordinator with their evaluation of each student. Finally, at the end of the academic year, the CSL coordinator submitted the students' final grade to the course instructor for a total of $100 \%$.

\subsection{The Community Partners}

The community partners we worked with are from four different organizations within the city. Specifically, Western students were to dedicate approximately two hours each week to work with one of the following organizations: The London Public Library, The Canadian Diabetes Association, LUSO Community Services and The AIDS Committee of London. Each community partner accepted a predetermined number of students and different projects were assigned to each of them.

At the London Public Library, Spanish students participated in the "One on One Conversation Mentor for the Spanish Speaking Newcomers Program." This program was developed in order to address an immense need for the newly arrived Hispanic population in order to build up their communicative competence in English. Thus, students were paired with an adult newcomer whose mother tongue was Spanish and although the objective of the program was to encourage the Learner to speak and understand English as it is spoken conversationally, this was a great opportunity for our students to practice their Spanish language skills, as well as learn more about their partner's culture. The meetings were two hours at a time and they dedicated one hour to speaking English and one hour to speaking Spanish. In many cases, our students made long lasting friendships with their partners that extended well beyond the duration of the CSL program.

At the Canadian Diabetes Association, our students worked on three different translating projects: the CDA Learning Series Presentations, different literature 
and the Banting House Museum Tour Guide. The Learning Series to be translated were a set of PowerPoint presentations used nationally by the Association. They are one of the vehicles used to educate communities about diabetes. Our students were required to translate and modify them to reflect the target population and make them culturally relevant. Once the work was completed, the presentations were shared with other CDA branches working with Latin American populations in Canada. The literature pieces that our students had to translate were mainly pamphlets and brochures used across Canada by the public and health care professionals in order to provide more education about diabetes. Finally, the London branch of the CDA is home to the Banting House National Historic Site of Canada - a museum attributed to the life if Sir Frederick Banting, discoverer of insulin. People from all over the world visit the museum and regular tours are offered to the public. Given the considerable number of Spanish speakers that visit the museum, the association wanted our students to also translate the tour manual so that in the future museum tours in Spanish would also be available. Evidently, the projects proposed by the CDA required an advanced level of Spanish and for this reason only students at this language level were assigned to work with this association. All translations done by our students were guided by the coordinator in order to ensure that the work was being done correctly, although the coordinator did not have any professional translation background.

LUSO Community Services is an organization that provides programs and services for children, youth, and families of diverse backgrounds. However, considering the large Hispanic population in London, the vast majority of those requiring their services are Spanish speakers. As such, the organization was interested in finding Spanish speakers to become part of their team. Some of our students' responsibilities at LUSO included assisting with follow up phone calls to Spanish speaking clients (booking appointments and gathering missing information for completion of their files), answering phone calls and assisting Spanish speaking clients with their requests, assisting the Employment Outreach Coordinator and the Newcomer Settlement Worker by translating for Spanish speaking clients with limited English skills during simulated work interviews and career counseling sessions.

Finally, at the AIDS Committee of London (ACOL) our students worked on a few different translation projects as well as participated in the "Network and Outreach" program by assisting ACOL educators with outreach at the Cross Cultural Learner's Centre and other venues in the city.

As seen in each case, students had plenty of opportunities to apply knowledge acquired in class to real life situations. Those students whose partnerships turned into friendships were able to take more away from the experience. The added bond allowed our students to get a closer look at the lives of recent immigrants in Canada with language barriers. Furthermore, all students who reported forming friendships also reported learning first-hand about different Hispanic traditions celebrated in their homes. The amount of culture and history that students learned was far beyond that taught in the classroom. The CSL program was certainly an invaluable learning experience for most of the students, especially as they had come to realize that their 
Spanish skills are required locally and they do not necessarily have to travel in order to apply what they learned in class.

\subsection{The Students}

As described in the previous section, student participation in this program was completely voluntary and was assigned on a first come first serve basis, keeping in mind however, that certain projects required a higher Spanish proficiency than others. For example, intermediate students (students enrolled in second year Spanish courses) were generally placed in the one-on-one tutoring program at the Public Library or with another organization where the tasks did not require high proficiency in the language. By the same token, due to the increased difficulty of the task, only advanced students were assigned to the organizations that needed translation work.

Once notified of their placement, students were required to attend the initial orientation meeting at the location of the community partner and then follow through with their commitment during the academic year, which included a total of 32 volunteer hours over a span of eight months. Those that failed to do so automatically lost $15 \%$ of their final grade in the course.

Their responsibilities at the university (besides regular class attendance) also included the following: attending the initial CSL Orientation meeting, participating in regular monthly meetings with the CSL coordinator, which was where the coordinator was able to keep track of each student's hours and make sure that there were no problems with the placement. If students had any questions about their upcoming reflections or issues with their placements, this was the time that they were able to be answered or resolved. Furthermore, students had to complete four online reflections as well as one final reflective presentation, which was done in-class so that everyone (those who did and did not participate in CSL) in the language class could hear about the CSL experience. These assignments were evaluated by the CSL coordinator. The reflections and the final presentations were the academic part of CSL and thus it was clearly explained that the reflective assignments were not to be mistaken by mere reproductions of the CSL experience. Rather, we considered the reflections to be the link that ties student experiences in the community to academic learning (Eyler \& Giles 171) and thus in their work, students were expected to actually ponder about their individual experience, abstract some meaning or knowledge from it and if possible, relate it to what they had learned in class. All reflections were written in Spanish and submitted online.

While the language instructor ran the language class, the CSL coordinator was exclusively dedicated to the students in the CSL program. The coordinator worked as a liaison between the community partners and the language department, making sure that the placements were running smoothly, that students were completing their volunteer hours, and grading their reflections and final presentation. In the case of our department, the role of the coordinator is given to a Ph.D. student who organizes the entire year and is in charge of everything that pertains to the program. 


\section{THE POST-CSL QUESTIONNAIRE: RESULTS}

Because this was the first time the CSL option had been offered in our program, we were counting on student feedback to help us better appreciate the effect of this experience at all levels. It was important for us to determine the overall attitude that our students had developed towards the CSL experience. Furthermore, it was important to receive their feedback on how it could be improved for the following years. However, we were also seeking answers to a few specific questions. First, we wanted to know whether participating in the CSL program had influenced students into further pursuing Spanish courses. A second issue that we were interested in was to determine whether students had discovered new opportunities where they could apply their Spanish knowledge. One challenge among most Canadian universities is maintaining students' interest in pursuing Spanish courses beyond the beginner and intermediate levels. The number of students significantly decreases from first to second year and even more so in upper years. From our experience teaching Spanish courses, the most common answer students give when asked why they chose to stop taking Spanish courses after the second year, is related to the fact that they do not see any opportunities this language can offer outside the field of teaching. In other words, students seem to think that the only future for someone studying Spanish is becoming a Spanish teacher. It was our hope that the CSL experience would show them that there are also other areas where they could apply their knowledge of Spanish. These are the first issues we will be reporting on in this section. We will then discuss the CSL effect on students' overall learning experience, as per the answers provided.

Table 1 below outlines the answers to the questions we are interested in for the purpose of this paper. Although the office of Service-learning at Western University had provided us with their standard questionnaire, we made slight changes to it in order to better suit our purposes.

There were a total of thirty-seven students that completed the questionnaire and the table below shows their answers to each of the three questions we will be discussing here. Students were asked to rate the statements in the questionnaire on a scale of one to five ( 1 -strongly disagree and 5 -strongly agree).

\begin{tabular}{|c|c|c|c|c|c|c|c|c|c|c|}
\hline \multirow{2}{*}{ Questions } & \multicolumn{2}{|c|}{$\begin{array}{l}\text { Overall } \\
(\mathrm{N}=37)\end{array}$} & \multicolumn{2}{|c|}{$\begin{array}{l}\text { LIBRARY } \\
(\mathrm{N}=23)\end{array}$} & \multicolumn{2}{|c|}{$\begin{array}{l}\text { LUSO } \\
(\mathrm{N}=4)\end{array}$} & \multicolumn{2}{|c|}{$\begin{array}{l}\mathrm{CDA} \\
(\mathrm{N}=7)\end{array}$} & \multicolumn{2}{|c|}{$\begin{array}{l}\text { ACOL } \\
(\mathrm{N}=3)\end{array}$} \\
\hline & mean & $\mathrm{SD}$ & mean & $\mathrm{SD}$ & mean & SD & mean & SD & mean & SD \\
\hline $\begin{array}{l}\text { Overall positive expe- } \\
\text { rience with partner }\end{array}$ & 4.4 & 0.7 & 4.3 & 0.6 & 4.5 & 0.5 & 4.1 & 0.8 & 4.8 & 0.3 \\
\hline $\begin{array}{l}\text { Experience influenced me } \\
\text { to continue with Spanish }\end{array}$ & 4.3 & 0.8 & 4.4 & 0.7 & 4.25 & 0.5 & 4.3 & 0.8 & 3.3 & 1.5 \\
\hline $\begin{array}{l}\text { Because of experience } \\
\text { I discovered relevance of } \\
\text { Spanish in fields other } \\
\text { than teaching }\end{array}$ & 4.2 & 0.8 & 4 & 0.8 & 4.75 & 0.5 & 4.3 & 0.8 & 4 & 1 \\
\hline
\end{tabular}


In the table above, we are reporting students answers overall as well as per Community Partner. This allowed us to determine whether one organization in particular had more impact on our students than others. As can be seen in Table 1 , the vast majority of the answers are above four, which indicates that most of the participants tended to "strongly agree" with the statements. The fairly low standard deviations show there was not much variation between answers, meaning that most of the students' answers were fairly close to the mean. As for a comparison between the experience with each individual community partner, there also does not seem to be much variation. Most students had a positive experience regardless of where they were placed. As far as the question addressing their intention of continuing taking courses in Spanish, it would appear that the experience at ACOL (the AIDS Committee of London) was the one with the least influence. However, the high standard deviation $(\mathrm{s} d=1)$, suggests different opinions among the students. Furthermore, considering there were only three students from that organization that completed the questionnaire (out of the four working there), this final result cannot be taken as significant. Means of four and above and low standard deviations on the last statement suggest that most students tended to "strongly agree" with the fact that the CSL experience has allowed them to see that knowledge of Spanish can be relevant to fields other than teaching.

The following section of the questionnaire (section 4) specifically addressed the learning aspect of the CSL experience. That is to say, aside from building on their Spanish language skills, was there any other learning that took place during the CSL experience? Table 2 summarizes students' answers on the four statements addressing this issue. After reading each statement, students were asked to rate it as (1) true, (2) neither true nor false or (3) false. Again, similar to Table 1, the first column outlines the overall results while the following ones are presented for each community partner that participated in the program.

\begin{tabular}{|c|c|c|c|c|c|c|c|c|c|c|}
\hline & $\mathrm{TAB}$ & E 2. & EARNI & $\mathrm{JG} T$ & ROUC & CSL & & & & \\
\hline \multirow{2}{*}{ Questions } & \multicolumn{2}{|c|}{$\begin{array}{c}\text { Overall } \\
(\mathrm{N}=37)\end{array}$} & \multicolumn{2}{|c|}{$\begin{array}{c}\text { LiBRARY } \\
(\mathrm{N}=23)\end{array}$} & \multicolumn{2}{|c|}{$\begin{array}{l}\text { LUSO } \\
(\mathrm{N}=4)\end{array}$} & \multicolumn{2}{|c|}{$\begin{array}{l}\mathrm{CDA} \\
(\mathrm{N}=7)\end{array}$} & \multicolumn{2}{|c|}{$\begin{array}{l}\text { ACOL } \\
(\mathrm{N}=3)\end{array}$} \\
\hline & mean & SD & mean & SD & mean & SD & mean & SD & mean & SD \\
\hline $\begin{array}{l}\text { Through CSL placement } \\
\text { I developed/enhanced } \\
\text { a new skill }\end{array}$ & 1.3 & 0.5 & 1.2 & 0.4 & 1.5 & 0.6 & 1.5 & 0.6 & 1.7 & 0.6 \\
\hline $\begin{array}{l}\text { Participating in CSL } \\
\text { increased my sense of civic } \\
\text { engagement and } \\
\text { social responsibility }\end{array}$ & 1.2 & 0.5 & 1.2 & 0.5 & 1.25 & 0.5 & 1.25 & 0.5 & 1 & 0 \\
\hline $\begin{array}{l}\text { CSL taught me something } \\
\text { new about community and/ } \\
\text { or social issue I did not } \\
\text { know much about }\end{array}$ & 1.1 & 0.3 & 1.2 & 0.4 & 1 & 0 & 1 & 0 & 1 & 0 \\
\hline $\begin{array}{l}\text { I would like to see CSL } \\
\text { incorporated into more } \\
\text { courses }\end{array}$ & 1.1 & 0.2 & 1.1 & 0.3 & 1 & 0 & 1 & 0 & 1 & 0 \\
\hline
\end{tabular}


The results in Table 2 suggest that CSL has been an enriching experience. The majority of the students have developed a new skill, have increased their sense of civic engagement, and learned something new about the Hispanic community. The overall results show that most participants rated the statements they were presented with as "true" and the low standard deviations (in some cases $\mathrm{sd}=0$ ) show very little or no variation among student answers. Within the individual organizations, it seems that approximately half of the students that were placed at LUSO, CDA and ACOL do not think they have acquired a new skill through the CSL experience. This result is to a certain extent surprising, especially for the CDA group, since most students had to learn how to use a new computer program in order to design the promotional and informational materials they had to prepare for the Association. As for the following question, it seems that most students agree (within each organization as well) that the CSL experience has increased their sense of civic engagement and social awareness. The mean scores of 1.1 and 1 and the very low standard deviations for the third statement (as outlined in Table 2), make it clear that almost all students consider they have learned something new about the Hispanic community in their city. Finally, there seems to be a consensus among the CSL participants that they would like to be able to benefit from this kind of experimental learning in other courses they are taking as part of their undergraduate program.

\section{DISCUSSION: IMPLICATIONS FOR LEARNING AND TEACHING}

Zlotkowski (1998, p. 3) defines CSL as a 'meaningful community service that is linked to students' academic experience through related course materials and reflective activities". According to this widely accepted definition, it can be concluded that the CSL experiment presented in this study was quite successful. Students enrolled in the Spanish program at Western University had the opportunity to apply Spanish language skills acquired in the classroom by working at different organizations in the city. Furthermore, they had the opportunity to look back at their experience and critically reflect on it in the form of four different written online posts and a final presentation that they shared with the rest of their classmates. The responses outlined in the previous section further support the success of this program.

As previously mentioned, it is a common phenomenon that first year Spanish language courses tend to be very popular with hundreds of students enrolling for the beginner level and then there is a significant drop in interest, and maintaining student enrollment becomes quite challenging. What we have noticed through the introduction of the CSL program is that those students who chose the CSL option became more involved in the classroom. Several students commented that they felt much more confident in speaking Spanish in class in front of their peers, simply because they got to practice outside of the classroom with a native speaker, where they were more concerned with communication and getting their point across. This program creates active learners; students who would be too scared to answer questions in class became more involved and engaged in classroom activities and 
discussions. The CSL option has given students the best of both worlds: although all Spanish classes within our program follow a communicative approach, where students have the opportunity to engage in many interactive activities, the reality is that much attention is also paid to teaching grammar and grammatical rules. The Service-learning option however, gave all participants the opportunity to apply what they learned in the classroom to real-life situations. Through this practical experience, students have the opportunity to actually see the relevance of the work done in the classroom and they are proud to be able to apply it.

From a pedagogical perspective, we have found that the quality of the work produced (both written and oral) is much higher. Students come to class prepared and excited to show that their CSL placement has helped them. Not only did they receive one-on-one language practice, they also learned a great deal about the culture of their partner's country, which is a lot more than any classroom could offer. On a larger scale, our students developed their language skills and they also grew as human beings by seeing how recent immigrants live in London, Ontario and getting an inside look into their daily struggles with their own language barriers.

\section{FUTURE DIRECTIONS}

Most scholars working in the field of Spanish CSL have focused on whether there was any evidence of improvement in students' communication and cultural skills as a result of their participation in CSL (Beebe \& De Costa, 1993; Darias et al., 1999; Hale, 1999; Jorge, 2003; Mullaney, 1999; Varas, 1999). In most cases, the findings were encouraging and it has been determined that CSL has an overall positive influence on these two factors. However, most of these studies have been carried out in the United States and not much has been reported on Spanish CSL in Canada. In that respect, the current paper aims to further add to this field of study and determine whether it could have the same impact in Canadian post-secondary institutions. The positive effects of CSL on language learning has been previously demonstrated by research on such programs in the US where opportunities for such initiatives are abundant due to the large Hispanic population that is part of the American society. Our results add to these previous findings by offering additional evidence that further supports the benefits of making experiential learning part of the CSL curriculum even in communities where the target language is not as widely spoken. Specifically, it shows that such positive experiences are also possible in Canada, despite the significantly lower Hispanic population. The main difference between the Canadian and the American CSL experience for Spanish language courses is probably the challenge in finding opportunities for our learners within the community, considering the already mentioned significantly reduced number of Hispanics in Canada. However, our initiative stands as proof that although more challenging, such experiences are not only possible but are found to be as successful as they are in the United States.

Furthermore, as one of the future goals - given the Linguistics and Second Language Acquisition background of the authors- it would be interesting to test 
and analyze one specific aspect of the Spanish language and determine whether CSL plays a role in the actual acquisition process of the language by comparing students in the CSL option with those in the regular classroom, especially since it is well known that opportunities for language production are significantly more limited in the classroom. These results could then be compared to study-abroad programs to test whether there is a significant difference between language acquisition abroad and CSL placements.

REVIEWS SENT TO AUTHOR: 1-3-2020; REVISED PAPER ACCEPTED FOR PUBLICATION: $1-7-2020$ 


\section{WORKS CITED}

Аввотт, A. \& D. Lear. "The Connections Goal Area in Spanish Community Service- Learning: Possibilities and Limitations." Foreign LanguageAnnals 43(2010): 231-245.

Astin, A.W., L.J. Vogelgesang, E.K. Ikeda \& J.A. Yee. How Service Learning Affects Students. Higher Education Research Institute UCLA, 2000.

BArReneche, G.I. "Language Learners as Teachers: Integrating Service-Learning and the Advanced Language Course.” Hispania 94/1 (2011): 103-120.

Beebe, R.M. \& E.M. De Costa. “Teaching Beyond the Classroom: The Santa Clara Eastside Project Community Service and the Spanish Classroom." Hispania 76/4 (1993: 884-891.

Bringle, R.G. \& J.A. Hatcher. "Implementing service learning in higher education.” Journal of Higher Education 67 (1996): 221-239.

Cone, D. \& S. Harris. "Service-Learning Practice: Developing a Theoretical Framework." Michigan Journal of Community Service Learning 3 (1996): 31-43.

Darias, T., A. Gómez, J. Hellebrandt, A. Loomis, M. Orendain \& S. Quezada. "Construyendo puentes (Building bridges): Concepts and models for service-learning in Spanish" (American Association for Higher Education series on service-learning in the disciplines). In Community video: Empowerment through university and community interaction. Ed. E. Zlotkowski (Series) \& J. Hellebrandt \& L.T. Varona (vol.), 1999. 149-169.

Dörnyei, Z. "Motivation in Action: Towards a Process-Oriented Conceptualization of Student Motivation." British Journal of Educational Psychology 70 (2000): 519-538.

Dörnyei, Z. The Psychology of the Language Learner: Individual Differences in Second Language Acquisition. Lawrence Erlbaum Associates, 2005.

Eyler, J. \& D. Giles. “Where's the learning in service-learning?” Jossey-Bass, 1999.

Gardner, R. \& W. Lambert. Attitudes and Motivation in Second Language Learning. Rowley. Newbury House, 1972.

Gass, S.M. \& L. Selinker. Second Language Acquisition. An Introductory Course. Routledge Taylor and Francis Group, 2008.

Hale, A. "Service Learning and Spanish: A Missing Link." In Construyendo Puentes-Building Bridges: Concepts and Models for Service-Learning in Spanish. Ed J. Hellebrandt and L.T. Varona. American Association for Higher Education, 1999. 9-31

Jorge, E. "Juntos: Community partnerships in Spanish and Portuguese." In Dialogue and power: Collaborative language curriculum development. Ed. C. Klein (Series) and J. Hellebrandt, J. Arries \& L.T. Varona (vol.). American Association of Teachers of Spanish and Portuguese professional development series handbook 5. Thompson Heinle, 2003. 17-28.

Kоцв, D. "Experiential learning: Experience as a source of learning and development." Inglewood Cliffs. Prentice-Hall, 1984.

Lightbown, P.M. \& N. Spada. How Languages Are Learned. Oxford University Press, 2008.

Metz, E., J. McLellan, \& J. Youniss. “Types of voluntary service and adolescents' civic development." Journal of Adolescent Re-search 18 (2003): 188-203.

Montrul, S. Incomplete Acquisition in Bilingualism. Re-examining the Age Factor. John Benjamins Publishing Company, 2008. 
Sigmon, R.L. "Service-Learning: Three Principles.” Synergist 8/1 (1979): 9-11.

Varona, L.T. "La comunidad en el aula y el aula en la comunidad: Un modelo." Hispania 82/4 (1999): 806-816.

Wurr, A.J. \& J. Hellebrandt. Learning the Language of Global Citizenship: Service-Learning in Applied Linguistics. Anker, 2007.

Zapata, G.C. "The Effects of Community Service Learning Projects on L2 Learners' Cultural Understanding." Hispania 94/1 (2011): 86-102.

Zapata, G.C. \& W. Tokarz. "Community Service Learning and L2 Students' Intercultural Communicative Competence." In Readings in Language Studies, volume 1: Language Across Disciplinary Boundaries. Ed. M. Mantero, P. Chamness Miller, and J.L. Watzke. International Society for Language Studies, 2008. 281-297.

Zlot коwsкi, E. “A new model of excellence.” In Successful Service-Learning Programs. New Models of Excellence In Higher Education. Ed E. Zlotkowski. Anker Publishing, 1998. 1-14. 
